\title{
Introduction: Images of Migration in the Hebrew Bible
}

\author{
Tchavdar S. Hadjiev \\ Belfast Bible College/Queen's University Belfast, u K \\ t.hadjiev@qub.ac.uk
}

The beginnings of this volume go back to an academic conversation that took place in 2016 at a conference on Bible and Migration. The conference was held in Trinity College Dublin's Centre for Biblical Studies, a location which seemed particularly appropriate, given the ways in which the identity and global influence of Ireland have been shaped by ongoing immigration and emigration over the centuries. ${ }^{1}$ The most pertinent features of our wider context at that time were the ongoing war in Syria and the refugee crisis in Europe. Subsequent to our conference, and as we were preparing the papers for publication, the UK voted for Brexit, excited by the prospect of being able to 'take back control of [its] borders,' while in the us Donald Trump, who promised a 'beautiful wall' on the border with Mexico and tougher measures against illegal immigrants, was elected as president. The French presidential elections a few months later, however, went in the opposite direction rejecting anti-immigration rhetoric. These were only a few of the most high profile recent events that continually underscored the significance and relevance of our chosen topic.

Migration is a complex phenomenon that touches on various aspects of social life: employment and the economy, environmental policy, identity and culture, the place of the law. ${ }^{2}$ In addition, it raises a number of important philosophical and ethical questions. Is there a human right to freely move across borders, or do nation-states possess the moral (and not just the legal)

1 See, for example, E. Delaney, 'Migration and Diaspora', in A. Jackson (ed.), The Oxford Handbook of Modern Irish History (Oxford: Oxford University Press, 2014), pp. 126-47.

2 For a useful summary of the arguments relating to these areas on both sides of the immigration debate in the North American context, see E.W. Collier, 'Arguing about Immigration: The Claims of Restrictionsts and Non-Restrictionists', in E.W. Collier and C.S. Strain (eds.), Religious and Ethical Perspectives on Global Migration (Lanham: Lexington, 2014), pp. 229-55. 
authority to restrict the access of outsiders and to control who comes in? ${ }^{3}$ How have colonialism and globalisation impacted migration and what is the moral responsibility of the Western world when migration is placed in this broader context? ${ }^{4}$ In view of the close connection between immigration controls and racism that has existed historically and is, arguably, still a feature of current practice, can we discuss migration with any sort of integrity without facing up to the demons of racial prejudice ${ }^{5}$ The string of terrorist attacks in recent years have polarised the debate even further, adding security to the long list of concerns people have about migration, and the religious and ethnic minorities that eventually arise from it. According to one recent scholar, these attacks have laid bare the 'quasi-suicidal nature' of the ethos of Western democracies, as they face a pressing dilemma to either 'retain their ethos of hospitality and leave themselves open to attack from without and within; or cut back on their freedoms, fortify their borders, betray, corrupt and threaten their ethos in order to protect it.' ${ }^{\prime}$ This is a difficult choice to be faced with.

Migration is intimately linked to religion on a number of levels. It is not just that migration transforms religion and religion facilitates migration. ${ }^{7}$ Both as social phenomenon and as human drama, migration invites various communities of faith to theological engagement and reflection in a special and powerful way. ${ }^{8}$ Recent years evidence an increasing interest in the topic on the part of biblical scholars as well. As far as the Hebrew Bible is concerned, the Babylonian exile, unsurprisingly, has received the lion share of attention. This and subsequent periods saw the emergence of numerous Judean migrant commu-

3 Contrast K. Oberman, 'Immigration as Human Right', in S. Fine and L. Ypi (eds.), Migration in Political Theory: The Ethics of Movement and Membership (Oxford: Oxford University Press, 2016), pp. 32-56 and J.L. Coleman and S.K. Harding, 'Citizenship, the Demands of Justice, and the Moral Relevance of Political Borders', in W.F. Schwartz (ed.), Justice in Immigration (Cambridge Studies in Philosophy and Law; Cambridge: Cambridge University Press, 1995), pp. 18-62.

4 O. Otunnu, 'Root Causes of Forced Migration in Africa', in E.W. Collier and C.S. Strain (eds.), Religious and Ethical Perspectives on Global Migration (Lanham: Lexington, 2014), pp. 58-64. See also in the same volume M. Friedmann Marquardt, 'Double Threat? Unauthorized Migration as a Global Phenomenon', pp. 13-33.

5 S. Fine, 'Immigration and Discrimination', in S. Fine and L. Ypi (eds.), Migration in Political Theory: The Ethics of Movement and Membership (Oxford: Oxford University Press, 2016), pp. $125-50$.

6 D. Bulley, Migration, Ethics \& Power: Spaces of Hospitality in International Politics (Sage: London, 2017), p. 154.

7 C. Plüss, 'Migration and the Globalization of Religion', in P.B. Clarke (ed.), The Oxford Handbook of the Sociology of Religion (Oxford: Oxford University Press, 2009), pp. 491-98.

8 See especially E. Padilla and P.C. Phan (eds.), Theology of Migration in the Abrahamic Religions (New York: Palgrave Macmillan, 2014). 
nities in Mesopotamia, Egypt and further afield as a consequence of war and economic hardship. John Ahn has examined how various texts from the Psalms, Jeremiah, Isaiah, and Numbers reflect the experiences of the first few generations of migrants. ${ }^{9}$ The 'Exile-Forced Migrations in Biblical Literature' programme unit of the Society of Biblical Literature's Annual Meeting has recently produced a volume on the prophets that concentrates roughly on the same historical period. ${ }^{10}$

The present volume seeks to contribute to this growing body of work on migration in the Hebrew Bible in a number of different ways. The essays here focus on Hebrew narratives that are set in the distant past - the patriarchal period, the exodus, and the time of the judges. Yvonne Sherwood looks at the story of Hagar; Katherine Southwood examines the narratives of the Levite's concubine, Lot, and Dinah; Casey Strine provides a reading of the Jacob cycle; Gregory Lee Cuéllar and Tchavdar Hadjiev both explore the early chapters of Exodus; David Shepherd probes the story of Ruth in connection with Judges 19. Even if these narratives were written or redacted during the exile, they still purport to depict a much earlier period of Israel's history, prior to the rise of the monarchy. The way they imagine those early stages is again profoundly shaped by the experience of migration.

The end result is that the Hebrew Bible in its final canonical form presents biblical Israel essentially as a migrant people. Their ancestors journey from Mesopotamia, to Canaan, to Egypt. They depart from Egypt to sojourn in the wilderness and finally enter Canaan, the 'Promised Land' that is to become their home, a place to belong. Yet, the people's arrival there is neither the climax, nor the end of the story, just a mid-point in a long, winding journey that constantly swings between belonging and alienation, native and foreign, home and away. Mesopotamia, Canaan, and Egypt describe a triangle marked by the constant flow of exiles and exoduses, deportations and returns.

Even though the essays here focus on this relatively coherent selection of narratives, they present a wide variety of methods and approaches. Sherwood uses the figure of Hagar as the paradigmatic resident alien who, in her utter strangeness and otherness, problematises our identity, reminds us that its beginnings lie somewhere outside of us, and calls us to solidarity with the stranger. Southwood explores the ambiguous and potentially problematic nature of

J.J. Ahn, Exile as Forced Migrations: A Sociological, Literary, and Theological Approach on the Displacement and Resettlement of the Southern Kingdom of Judah (BZAW, 417; Berlin and New York: de Gruyter, 2011). See also Bo H. Lim, 'Exile and Migration: Towards a Biblical Theology of Immigration and Displacement', Covenant Quarterly 74 (2016), pp. 3-15. 
the concept of hospitality, its relation to sexual violence, and to the different ways power relations between hosts and migrants can be construed. Strine advocates a reading of the Jacob cycle that utilises social-scientific models of migration and provides fresh exegetical insights based on them. Cuéllar stresses the journey element in Exodus 2 and suggests a migrant-centred reading that mirrors the experiences of unaccompanied children who seek to cross the UsMexican border. Hadjiev experiments with the same narrative, proposing to identify modern-day, Western readers with the 'villains' of the story (the Egyptians) in order to aid self-critical reflection on the validity of current attitudes towards foreigners. Shepherd returns to the topic of sexual violence against migrants by looking at the book of Ruth and highlighting a hitherto neglected aspect of the story, namely the relationship between Ruth's foreignness and the danger of sexual abuse that hangs over her head as she gleans in the Judean countryside.

The final contribution to the volume is a social scientist's response to the essays. Gillian Wylie points out the 'striking timelessness' of the stories explored, as she makes even more explicit their connection to modern-day realities of migration. The Hebrew Bible reminds us that the politics of exclusion, suspicion, and fear are not a new phenomenon. On the other hand, the narratives recognise migrants' agency and the availability of alternative, more inclusive and humane, ways of dealing with the other. In all this, Wylie notes, the stories 'contain much which is by turns disturbing and hope inducing'. 